\title{
PROPERTY INDEX AND HYDROPHYSICAL CONDITIONS OF SOILS AT SUBSIDENCESS IN PONJONG, RONGKOP AND SEMANU SUBDISTRICTS, GUNUNGKIDUL DISTRICT
}

\author{
Rijali Isnain Haripa ${ }^{1}$, Astrid Damayanti ${ }^{2,}$ and Tito Latief Indra ${ }^{3}$ \\ 1,2,3 Department of Geography, Universitas Indonesia
}

*Corresponding Author, Received: 10 Feb. 2020, Revised: 13 April 2020, Accepted: 23 April 2020

\begin{abstract}
Karst Gunung Sewu is a tropical Karst area with unique features like a sinkhole or doline. Sinkhole or doline usually formed due to subsidence. Ponjong, Rongkop, and Semanu subdistricts in Gunungkidul District are areas that included in the Karst Gunung Sewu area, which has a high frequency of land subsidence. The purpose of this research is to identify the soil physical characteristics in the subsidence area in the karst units. This research method includes mapping, geotechnical investigation, and laboratory tests to determine soil physical properties. In the research area, 41 subsidence points occurred in six karst units. The physical characteristics of the soil around subsidence in that subdistrict show that the soil has a medium texture with the attributes of fine clay. Atterbag boundary values in subsidence soil are more than $50 \%$. It was causing the soil to have a high level of plasticity. The soils conditions in the subsidence area have low permeabilities and reduced porosity. It has deep to shallow soil thickness with good drainage until obstructed. These characteristics of the soil cause the potential for ground movement, such as subsidence, especially when there is a water thrusting during a flood.
\end{abstract}

Keywords: Permeability, Plasticity, Property Index, Soil, Subsidences

\section{INTRODUCTION}

The Karst region in Indonesia included in the Karst region of the tropics. One of the Karst regions in Indonesia that is complex and best and representing as tropical Karst is the Karst area of Gunung Sewu [1]. The Gunung Sewu Karst shows traces of tectonic activity, erosion, denudation, and deposition from the Miocene era. Karst Gunung Sewu shows a specific tropical formation because characterized by the appearance of hills, closed depression, and existing caves. Among the presence of the landform, sinkhole or subsidence is quite a lot found in the area.

This diverse and sophisticated form of Karst land developed from a sinkhole or doline. Sinkhole or doline usually formed due to subsidence. Ponjong, Rongkop, and Semanu Districts in Gunung Kidul Regency are areas that belong to the Gunung Sewu Karst area, which have high subsidence frequency [2]. One of the studies on the development of subsidence assessed by the physical condition of the land around it. Sinkhole formation begins with subsidence. There is a sinkhole that develops naturally, and there is a result of human intervention [3].

Naturally, subsidence can occur due to movement from the ground due to external forces such as water. The existence of soil movement is related to soil mechanics, which is part of the physical properties of the land[4]. Sinkhole as a geomorphological feature can change the spatial distribution of soil moisture due to water stagnation in floodplains or changes in the spatial distribution of air temperature and humidity as well as the depth of the soil in the karst region [5].

There are differences in this study with previous studies, which are the variables and methods used. In previous studies, most of the objectives were to see the potential for subsidence. Previous studies used more modeling methods [6,7]. In this study, the main aim is to analyze the relationship between soil properties and the occurrence of subsidence by identifying the physical properties of the soil around it in Ponjong, Rongkop, and Semanu subdistricts. The identification of soil properties is carried out on subsidences in each unit of geomorphology. This research focuses on the property index and hydrophilic properties of the soil around subsidences.

\section{METHODOLOGY}

To obtain the data needed in this research, the method used is geological mapping and geotechnical investigation (field and laboratory). Geotechnical investigations were carried out to collect data on physical characteristics and surface engineering. Geotechnical investigations consist of sampling disturbed soils. Mapping the subsidences 
location by verifying the point from the actual data that has been done previously [8]. The data used are primary data and secondary data. The sample points for primary data collection are determined based on purposive sampling. The subsidence point refers to secondary data from previous studies taken from several references $[8,9]$ in the Districts of Ponjong and Semanu. Besides that, data sinkhole or subsidence points also collected from the Disaster Management Agency of Gunungkidul District (Badan Penanggulangan Bencana Kabupaten Gunungkidul /BPBD). In this study, the primary data taken from the field were soil samples.

\subsection{Sample}

Soil samples are the primary data in this study. Soil samples taken at the subsidence site are tested in a laboratory to see soil characteristics. Soil samples that had taken are disturbed soil for property index and undisturbed soil for hydrophysical properties. Undisturbed soil samples are soil samples taken from soils that do not have significant surrounding coverage and are not crossed by roots. Soil samples are made using a soil ring tool. In addition to primary data, there are also supporting data or what is commonly called secondary data.

Secondary data referred to in this study are data not obtained from direct measurements in the field, but supporting data collected from the relevant government agencies or institutions. These data are useful for making thematic maps related to the research conducted. The thematic maps are helpful as primary data in the study. Digital Elevation Model Nasional (DEMNAS) from BIG is data to obtain slopes and heights as geomorphological elements. Then there is also a geological map and soil type data used as a reference to create a soil map that used as a research reference.

\subsection{Soil Conditions}

There are two land condition data referred to in this study. The first condition is the soil property index data, which includes texture and atterbag limits (plastic properties of the soil). Hydrophysic soil data provided permeabilities, bulk densities, and porosity. All soil conditions were tested by a laboratory to determine the value of each property. These five characteristics are physical properties that are suitable for knowing the nature of subsidences. It related to engineering and hydrologic factors that drive subsidence [10]. After conducting laboratory tests, soil condition variables weighted into several classifications of soil characteristics [11].

\subsection{Analysis}

The samples that have been processed are analyzed to get the desired results. There are two analyzes used in this research, which are overlay analysis and descriptive spatial analysis. The first analysis is used to analyze the geomorphological unit in the study, which is obtained by combining several variables. These variables are analyzed by overlapping or commonly referred to as overlays. The second analysis is to describe the observed variables spatially. Descriptive spatial analysis can describe the distribution of results based on the unit of analysis used. In this study, a descriptive spatial analysis was carried out to explain the results of the overlay and laboratory tests.

\section{RESULT}

\subsection{Geomorphological Unit}

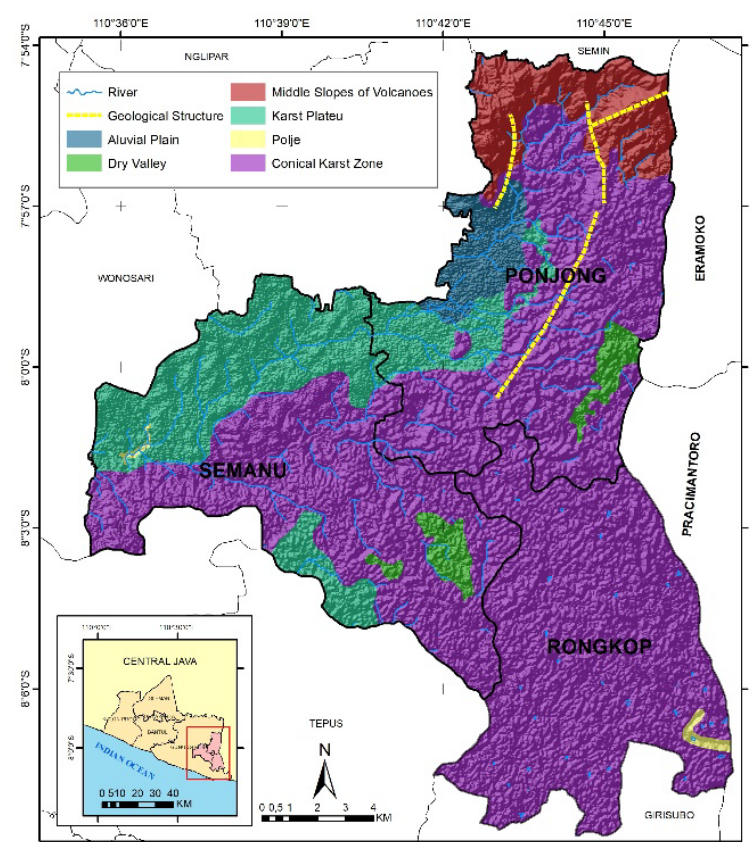

Fig. 1 Geomorphological Unit in Ponjong, Rongkop, and Semanu

The location of the subsidences in Ponjong Rongkop and Semanu sub-districts were analyzed based on the geomorphological unit area. There is an association between subsidences and the formation of karst landscapes. In general, the geomorphological unit in the study area belongs to the karst landscape group, and only a small portion is non-karst. There are six landforms or geomorphological units in Ponjong, Rongkop, and Semanu subdistricts. The six geomorphological units are the Alluvial Karst Plain, Dry Valleys, the Central Slopes of Volcanoes, the Karst Plateau, the Polje, and the Konical Kars Zone shown in Figure 1.

\subsubsection{Alluvial Plain of Karst}

The first geomorphological unit is the alluvial plain symbolized in blue on the map and K7 code. 
Karst alluvial plain has flat topographic characteristics (slope $<2 \%$ ), surrounds residual hills, deep soil solum, drainage well-somewhat obstructed. More clearly, the alluvial terrain of Karst seen in Figure 2 (a). This geomorphological

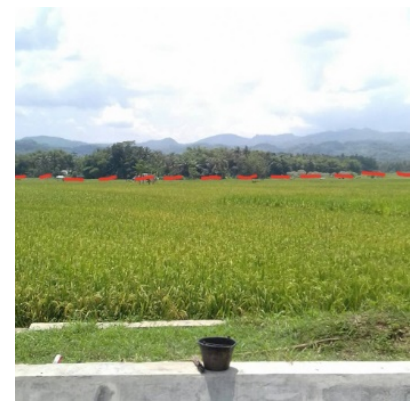

Karst Alluvial Plain in Genjahan

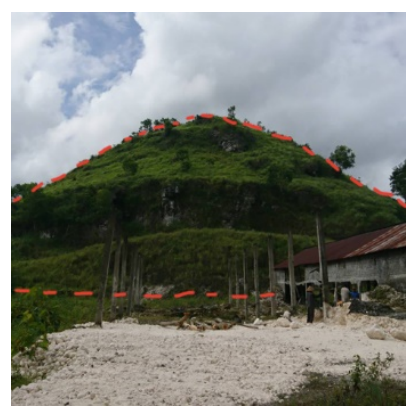

Conical Karst Zone in Petir

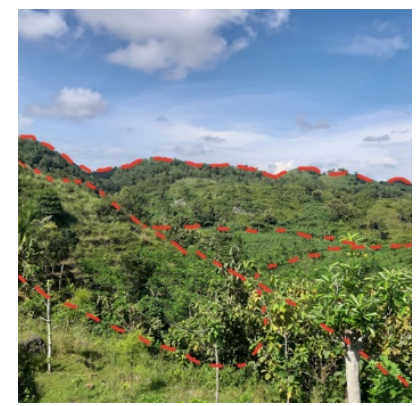

Dry Valley in Dadapayu Village

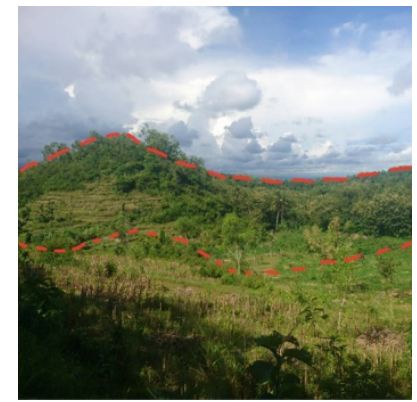

Karst Plateau in Pacarejo Village

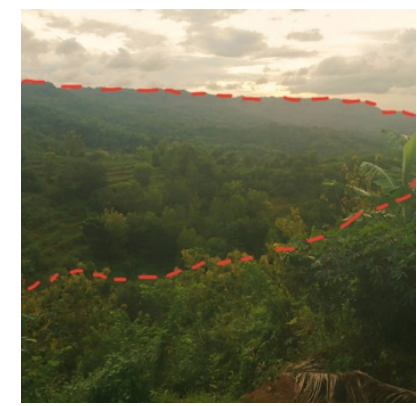

Middle Slopes of Volcanoes in Tambakromo Village

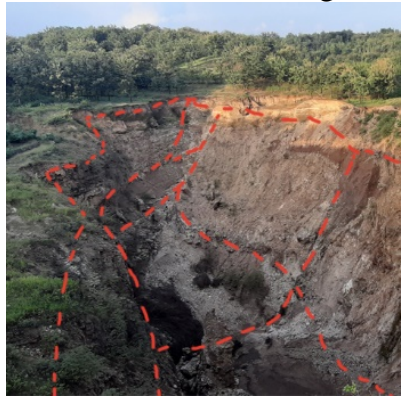

Polje in Pacarejo

Fig 2. The Example of 6 kind Geomorphological Unit in Ponjong, Rongkop, and Semanu

\subsubsection{Dry Valley}

The second geomorphological unit is Dry Valley (K10), as shown in Figure 2(b). This geomorphological unit is not too large and extensive in the study area. The area of dry valley geomorphology unit is $7.08 \mathrm{~km}^{2}$ or $2.44 \%$ of the total area. Dry Valley found in Karangasem Village, Ponjong District, and Dadapayu Village in Semanu District.

\subsubsection{Middle Slopes of Volcanoes}

The third geomorphological unit is the Central Valley of Volcano Light, as shown in Figure 2@ This geomorphological unit is no longer included in the Gunung Sewu Karst Area and is incorporated into the Volcanic Group (V6). This geomorphological unit has the characteristics of a rather steep slope and rough - hilly topography. It has semi radial or parallel drainage patterns, and incision forms usually resemble U-shape, good drainage, soil types are generally andosol or alfisol. The soil solum is rather deep $(>50 \mathrm{~cm})$ incised moderately - this volcanic geomorphological unit located in the north of the Ponjong District, which is already hilly.

\subsubsection{Conical Karst Zone}

The fourth landform is the Conical Karst Zone (K5), as shown in Figure 2 (d). This geomorphological unit has the characteristics of an undulating topography - hilly, very steep slopes, round-shaped like a dome. This geomorphological unit is the most dominant landform in Ponjong, Rongkop, and Semanu Districts. This geomorphological unit has an area of $186.07 \mathrm{Km} 2$ or around $64.17 \%$. This landform is a characteristic of the Gunung Sewu Karst, which has cone hills and cockpits. This geomorphological unit is spread from the south of the study area or the entire Rongkop District to the North to the Ponjong and Semanu Districts.

\subsubsection{Karst Plateau}

This fifth geomorphologic unit has choppy topographic features with dissolving holes and small crack valleys. Kato Plato is one of the large geomorphological units in the Districts of Ponjong, Rongkop, and Semanu, with an area of $65.77 \mathrm{Km} 2$ or about $22.68 \%$. This landform distributed in the northern part of the research area. More clearly, the geomorphological unit showed in Fig 2(e).

\subsubsection{Polje}

The sixth form of land is the elongated valley or Polje (K9), as in fig 2(f). This geomorphological 
unit has the characteristics of a broad valley extending into a fault zone, often flooded with water. Polje has 2 locations: Melikan, Rongkop District, and Pacarejo in Semanu. This geomorphological unit has an area of $1.22 \mathrm{Km} 2$ or about $0.42 \%$ of the area.

\subsection{Subsidence Locations}

In the Districts of Ponjong, Rongkop, and Semanu there are subsidence locations. The subsidence location points in the study area obtained from the study of Riadini [8] and data from BPBD [2]. Based on these data and after field verification, the subsidence in Ponjong, Rongkop, and Semanu Districts divided into old subsidence and new subsidence. The determination of the old and new time of each subsidence is 2017. This early subsidence usually formed as luweng and doline.

The new subsidence created after 2017. The determination of the time of the latest and old subsidence class is 2017. The decision of 2017 is because, in November 2017, there was a Cempaka Storm, which caused massive flooding in Gunungkidul Regency. After the flooding, new. sinkhole holes emerged, especially in the Districts of Ponjong, Rongkop, and Semanu. Based on secondary data collected and the results of field verification found 41 points of subsidence in the Districts of Ponjong, Rongkop, and Semanu, as shown in Figure 3 The 41 subsidence divided into 24 new subsidence and 17 old subsidence. The early subsidence is denoted by A1 - A17, while the new one indicated by A18-A41.

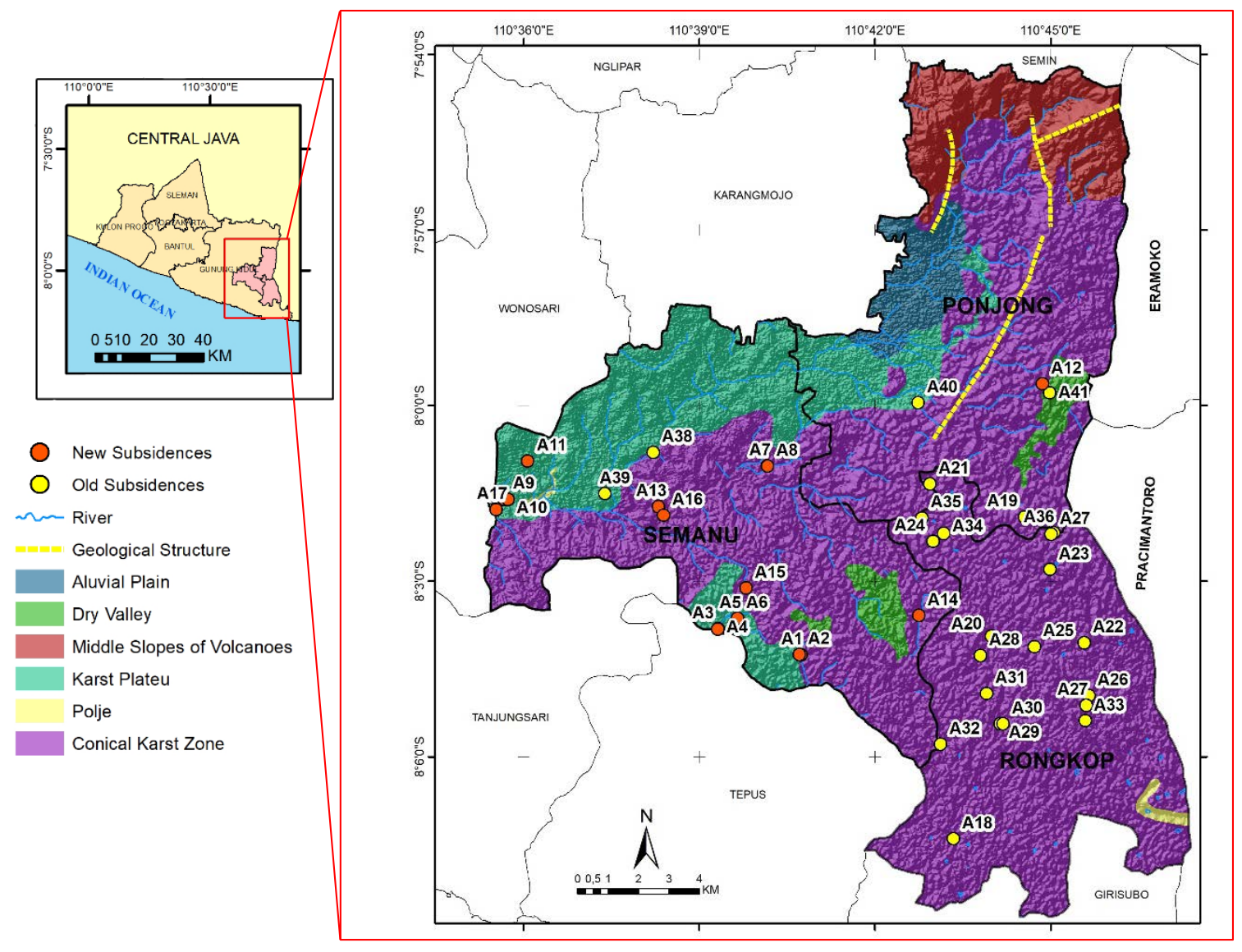

Fig 3. Distribution of Subsidence Locations

The subsidence that occurred in Ponjong, Rongkop, and Semanu Districts found in 3 geomorphological units, which were Konikal Karst (K5), Kato Plateau (K1), Polje (K9) and Karst Dry Valley (K10). In other geomorphological units such as the Alluvial Plain and the Central Valley of Volcanoes, no subsidence found. That was also because the geomorphological unit was transitional and no longer included the Gunung Sewu Karst Area. Subsidence most commonly found in the geomorphological units of the conical Karst zone.

Based on calculations, the number of subsidence in the geomorphological unit of the Karst Conical Zone is 25 . Then 13 subsidence is found in the Karst Plateau. Then there are two sinks in the dry valley and 1 in Polje. Examples of subsidence in the Districts Ponjong, Rongkop, and Semanu have more clearly seen in Figure 4. 


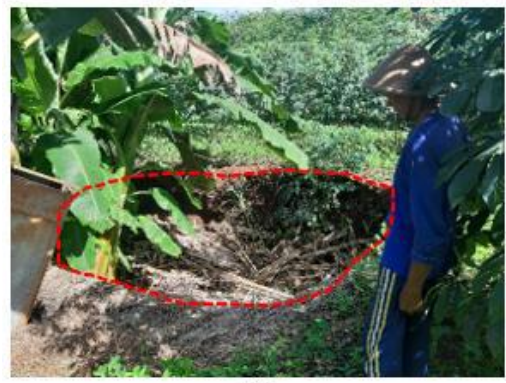

(a)

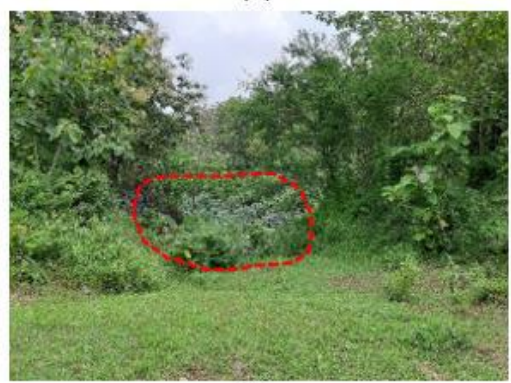

(c)

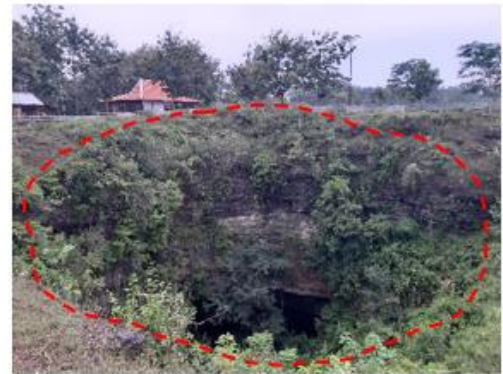

(e)

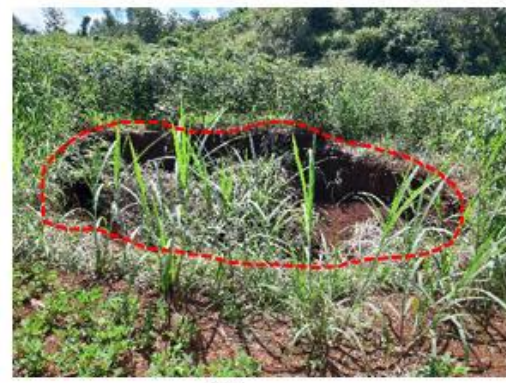

(b)

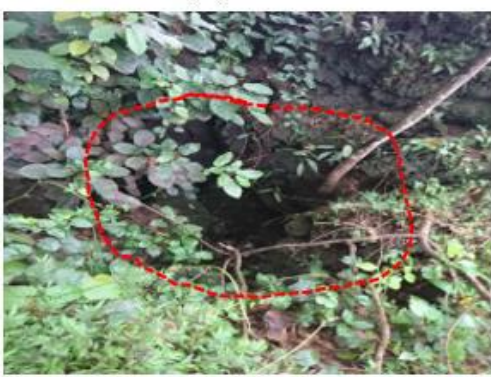

(d)

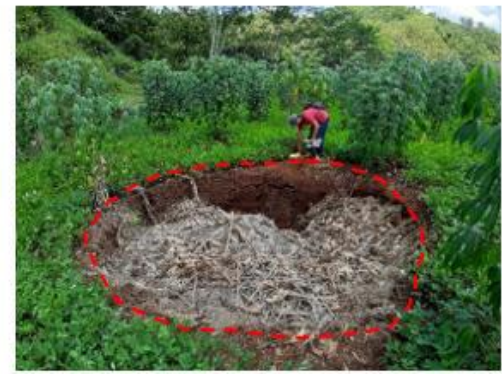

(f)

Fig 4. Sample of Subsidence Locations. (a) Rongkop (A19), (b) Rongkop 2 (A25), (c) Dadapayu (A14), (d) Ngeposari (A7), (e) Candirejo (A15), (f) Bedoyo (A19)

\subsection{Physical Characteristics of Soil Subsidence}

\subsubsection{Property Index}

a. Atterbag Limit

Table 1 Atterbag Limits Classification

\begin{tabular}{ccccc}
\hline $\begin{array}{c}\text { Subsidemce } \\
\text { Location }\end{array}$ & $\begin{array}{c}\text { PL } \\
(\%)\end{array}$ & $\begin{array}{c}\text { LL } \\
(\%)\end{array}$ & $\begin{array}{c}\text { PI } \\
(\%)\end{array}$ & Classified \\
\hline A25 & 38.31 & 65.59 & 27.285 & $\mathrm{MH}$ \\
A18 & 42.81 & 64.96 & 22.15 & $\mathrm{MH}$ \\
A19 & 37.64 & 63.72 & 26.08 & $\mathrm{MH}$ \\
A7 & 48.50 & 69.25 & 20.76 & $\mathrm{MH}$ \\
A14 & 38.77 & 58.96 & 20.19 & $\mathrm{MH}$ \\
A15 & 41.5764 .28 & 22.71 & $\mathrm{MH}$ \\
\hline
\end{tabular}

Testing in the laboratory is carried out for testing soil samples taken at 6 points. Soil sampling was chosen based on the geomorphological unit map that made. Rongkop 1, 2 Bedoyo are new subsidences, while the Ngeposari, Dadapayu, and Candirejo points are the old ones. This limit bag serves to see the level of the plasticity of a soil. From the lab test results, it can be seen that at sample point A25 in Rongkop 1 Village. It has a value of Liquid Limit (LL) 65.59\%, Plastic Limit (PL) 38.31\%, and Plastic Index (IP) 27.28\%. The sample point A18 in Rongkop 2 has an LL value of 64.96\%, PL 42.81\%dan PI 22.15\%. Sample A7 in Ngeposari has value off LL 69.25\%, PL 48.50\%, and PI 20.76\%. The Dadapayu sample point has an LL value of $58.96 \%$, PL $38.77 \%$, PI 20.1.

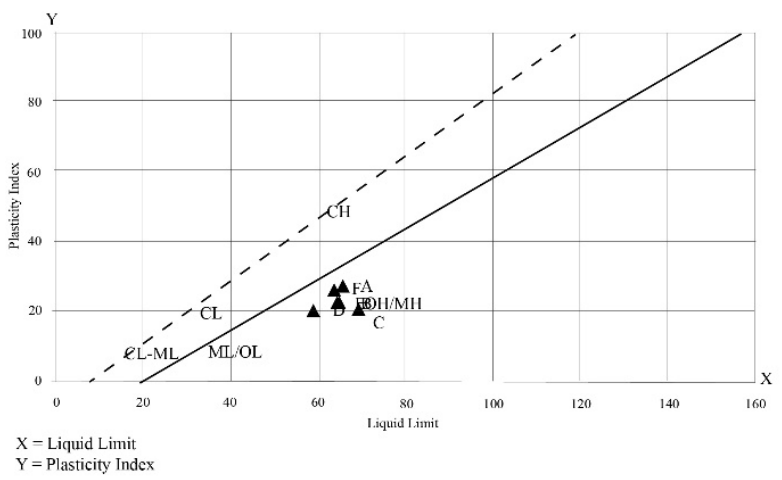

Fig 2. Plasticity Chart 
Bedoyo sample point has an LL value of $63.72 \%$, PL 37.64\%, and PI 26.08\%. Candirejo sample point has a value of LL 64.28\%, PL 41.57, and PI 22.71\%. A summary of the values of these test results seen in Table 1 and the chart of the plasticity shown in Figure 5.

\section{b. Soil Texture}

The soil texture consists of three fraction components, namely clay (clay), silt (silt), and sand (sand). Based on the test results at each sample point, the soil texture in this study area has similarities, namely medium texture. Soil texture tests are carried out in the laboratory to get accurate results. Laboratory test results show in Table 2.

Table 2 Soil Texture Classification

\begin{tabular}{cccc}
\hline \multirow{2}{*}{$\begin{array}{c}\text { Subsidences } \\
\text { Location }\end{array}$} & \multicolumn{3}{c}{ Composition (\%) } \\
\cline { 2 - 4 } & Clay & Sand & Silt \\
\hline A25 & 10.5 & 4 & 85.5 \\
A18 & 12.5 & 5 & 92.5 \\
A19 & 14.5 & 7.5 & 78 \\
A7 & 10.5 & 5.5 & 84 \\
A14 & 10.5 & 5 & 84.5 \\
A15 & 8.5 & 4 & 87.5 \\
\hline
\end{tabular}

Based on table 2, it is seen at the first sample location, which is A25 precisely in Semugih Village; the fraction composition is $10.5 \%$ clay, $4 \%$ sand, and $85.5 \%$ silt. At the second sample point, A18 in the Botodakan Village, the texture composition was $12.5 \%$ clay, 5\% sand, and $92.5 \%$ silt. At the third sample point, A19 in Bedoyo Village, the texture composition was $14.5 \%$ clay, $7.5 \%$ sand, and $78 \%$ silt. These three sample points are new subsidence. At the fourth sample point, Ngeposari, the fraction composition of the soil texture is $10.5 \%$ clay, $5.5 \%$ sand, and $84 \%$ silt. The fifth sample point or Dadapayu has a texture composition of $10.5 \%$ clay, $5 \%$ sand, and $84.5 \%$ silt. At the last sample point, Candirejo, the formation of the soil texture fraction was $8.5 \%$ clay, $4 \%$ sand, and $87.5 \%$ silt.

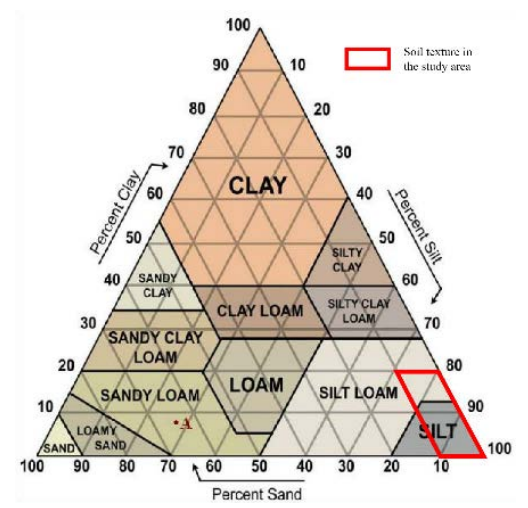

Fig 3. Triangle Texture of Subsidence Soils in the Study Area
These previous three sample points are old subsidence. Then, look at the position of the three composition fractions from each sample point on the soil texture triangle. Because all samples have the same relative composition of the dominant fraction, silt, the location of the triangle texture also tends to be the same for the silt fraction. More clearly, the site of the composition of the soil texture fraction of the subsidence point in the study area shown in Figure 6.

\subsubsection{Hydrophysical Soil a. Soil Permeability}

Soil permeability is the ability of soil to carry on water or air. Laboratory tests were carried out on ten samples. Test results show that soil permeability in Ponjong, Rongkop, and Semanu districts is low to moderate. The lowest soil permeability is in location A15 and A18, which found in the Botodakan, Rongkop, and Candirejo Village, Semanu. The complete results of permeability classification are in table 3.

\section{b. Bulk Density}

Bulk density is the ratio of the weight of dry soil to the unit of soil volume, which includes the volume of soil pores - generally stated in gr/cc. Bulk density is an indication of the challenging of the soil where the denser a soil, the higher the bulk density. It means that more challenging to continue water or penetrated by plant roots. In the study area, laboratory tests were performed to see the value of Bulk Density. Laboratory tests were carried out on ten subsidence samples. The lowest soil permeability is in location A15 and A18, which found in the villages of Botodakan, Rongkop, and Candirejo, Semanu. The complete results of permeability classification are in Table 3.

\section{c. Porosity}

Porosity is the proportion of total pore space (space) that can be occupied by air and water and is an indicator of drainage and soil aeration conditions. All samples in Ponjong Rongkop and Semanu Districts have proper porosity levels. In the ten samples that were taken, the highest porocytes were in the A25 sample in Botodakan Village, Rongkop. More clearly, the results of the porosity shown in table 3.

Porosity is the proportion of total pore space (space) that can be occupied by air and water and is an indicator of drainage and soil aeration conditions. All samples in Ponjong Rongkop and Semanu Districts have proper porosity levels. In the ten samples that were taken, the highest porocytes were in the A25 sample in Botodakan Village, Rongkop. More clearly, the results of the porosity shown in table 3 . 
Table 3 Classification of Soil Hydrophysical Properties

\begin{tabular}{cccccc}
\hline $\begin{array}{c}\text { Subsidence } \\
\text { Locations }\end{array}$ & $\begin{array}{c}\text { Permeability } \\
(\mathrm{cm} / \mathrm{hr})\end{array}$ & $\begin{array}{c}\text { Class of } \\
\text { Permeabilty }\end{array}$ & $\begin{array}{c}\text { Bulk Density } \\
\left(\mathrm{gr} / \mathrm{cm}^{3}\right)\end{array}$ & $\begin{array}{c}\text { Porosity } \\
(\%)\end{array}$ & $\begin{array}{c}\text { Type of } \\
\text { Porosity }\end{array}$ \\
\hline A2 & 1.82 & Rather Low & 1.10 & 58.66 & Good \\
A8 & 6.81 & Moderate & 1.06 & 59.85 & Good \\
A10 & 3.30 & Moderate & 1.18 & 55.32 & Good \\
A14 & 2.54 & Moderate & 1.07 & 59.56 & Good \\
A15 & 0.027 & Low & 1.24 & 53.26 & Good \\
A18 & 0.056 & Low & 1.08 & 59.38 & Good \\
A19 & 1.97 & Rather Low & 1.00 & 62.44 & Good \\
A25 & 0.05 & Low & 0.96 & 63.62 & Good \\
A33 & 2.73 & Moderate & 1.24 & 53.10 & Good \\
A40 & 3.11 & Moderate & 1.22 & 54.10 & Good \\
\hline
\end{tabular}

\section{DISCUSSION}

At the atterbag limit values, All sample points fall into the $\mathrm{MH}$ classification. $\mathrm{MH}$ classification is mineral mud, which incorporated in silt and mud soil associations, and finely ground soils. If the soil has a high liquid limit, the soil will move with water [12]. Soil with inorganic silt with a plastic limit of more than $50 \%$ have high degree compressibilities and plasticitylies, so that the movement of the soil is smooth, especially in areas with steep slope values [10].

Plastic soil causes water to push the soil down, not infiltrate into it. The ground movement also was seen from the values of hydrophysical properties. The texture that is making the compaction so that slowing the permeability of the soil because of the small pores that inhibit the movement of groundwater because the tiny pores that impede the flow of groundwater are getting higher. Besides that, in soil porosity conditions, sand soil has more rough pores than clay. Soil that contains a lot of coarse pores is challenging to hold water so that the soil is quickly dry. In contrast to the soil in the study area that has a medium texture or muddy clay, causing water to hold above and push the soil that has a cavity underneath, and finally, subsidence appears [12].

\section{CONCLUSION}

Land subsidences in the Districts of Ponjong, Rongkop, and Semanu, mostly occurs in the Conical Karst (K5), Plato Karst (K1), Polje (K9) and Dry Karst Valley (K10). However, in Karst Alluvial Plains and Central Valley Volcano Light, there are no subsidences found. That was also because the geomorphological unit was transitional and no longer included the Gunung Sewu Karst Area.

Soil characteristics in the subsidences in each geomorphological unit in Ponjong, Rongkop, and
Semanu Districts have similarities. The soil characteristics are smooth silt clay with high plastic value and low permeability, medium texture, proper Bulk Density and Porosity, and good drainage too. Inorganic silt with a plastic limit of more than 50\% has a high compressible degree and plastic, so that soil movement is natural, especially in areas with high slope values. This soil characteristic causes the high potential for soil movement in Ponjong, Rongkop, and Semanu Districts especially when there is a water thrusting during a flood.

\section{ACKNOWLEDGMENT}

Thanks are due to Directorate of Research and Community Service (DRPM) Universitas Indonesia, which has supported this research HIBBAH PITTA B UI 2019 with contract number NKB0579/UN2.R3.1/HKP.05.00/2019.

\section{REFERENCES}

[1] Kusumayudha, S. B., Setiawan, J., Ciptahening, A.N.,\&Septianta,P.D., Geomorphologic Model of Gunungsewu Kars, Gunung Kidul Regency, Yogyakarta Special Territory, Indonesia: The Role of Lithologic Variation and Geologic Structure. Journal of Geological Resource and Engineering, Vol.3, Issue 1, 2015, pp.1- 7.

[2] BPBD Gunungkidul District., Data on Subsidences Distribution in 2017., Yogyakarta: Center for Data and Reporting on Regional Disaster Management Agencies Gunungkidul. 2018.

[3] Delle Rose, M., Federico, A., \& Parise, M., Sinkhole genesis and evolution in Apulia, and their interrelations with the anthropogenic environment., Natural Hazards and Earth System Science, Volume 4, Issue 5/6, 2010, pp.747-75.

[4] Waltham, Tony. Bell, Fried. Chulshaw, M., For 
Chapter in a Book Sinkhole and Subsidence, Karst and Cavernous Rocks in Engineering and construction. Nottinghamshire: Praxing Publishing. 2005, pp.107 - 108.

[5] Ozdemir, A., Investigation of sinkholes spatial distribution using the weights of evidence method and GIS in the vicinity of Karapinar (Konya, Turkey). Geomorphology, Issue 245, 2015. pp.40-50.

[6] Zhou, G., Yan, H., Chen, K., \& Zhang, R. (2016). Spatial analysis for the susceptibility of second-time kars sinkholes: A case study of Jili Village in Guangxi, China. Computers and Geosciences, Issue 89, 2016, pp.144-160.

[7] Ogden, A.E., Reger, J.P. Morphometric analysis of dolines for predicting ground subsidence, Monroe County, West Virginia. In: Dilamarter, R.R., Csallany, S.C.(Eds.), Hydrologic Problems in Kars Regions. Western Kentucky University Press, 1997 pp. 130-139.

[8] Potential Areas of Soil Amblesan in the Kars Landscape in Ponjong and Semanu Districts, Gunung Kidul Regency Riadini, F., Depok: Department of Geography Faculty of Mathematics and Natural Sciences Universitas Indonesia: 2018, Thesis.
[9] Sari, D. F. N., Karstification Identification of Dolina Characteristics, Case Study: Ponjong and Semanu Subdistrict, Gunungkidul District. $2^{\text {nd }}$ National Geomatics Seminar, 2018, pp. 115.

[10] Mulyono, Asep \& Prahara Iqbal., Physical Characteristics of Landslides in the LiwaBukit Kemuning Transect Line, West Lampung. Lampung Technical Implementing Unit, Mining Engineering and Disaster Mitigation, LIPI-Liwa, Journal of Environment and Geological Disasters, Vol. 6 No. 1, April 2015: pp. 9-18.

[11] Arsyad, S., for Chapter in a Book,Soil Conservation. Bogor: Soil Sciences Major, Faculty of Agriculture, IPB University., 1979, pp.27.

[12] Hardjowige0no, Sarwono., For Chapter in a Book, Soil Sciences. Jakarta: Akademika Pressindo, 2007 pp.51-57.

Copyright (C) It. J. of GEOMATE. All rights reserved, including the making of copies unless permission is obtained from the copyright proprietors. 